\title{
EDITORIAL
}

\section{WASPADA SELAMA KEHAMILAN}

Menjadi ibu merupakan sesuatu yang diidamkan oleh setiap perempuan yang telah menikah. Kehamilan merupakan salah satu peristiwa yang sangat penting dalam diri seorang perempuan. Kehamilan yang tidak bermasalah dan berjalan dengan lancar sampai persalinan merupakan hal yang diharapkan oleh setiap ibu hamil. Tetapi tidak semua kehamilan berjalan sesuai dengan yang diharapkan. Beberapa ibu hamil mengalami kesulitan bahkan komplikasi pada kehamilannya. Komplikasi yang diderita ibu hamil akan mengancam jiwa ibu hamil itu sendiri dan juga janin yang dikandungnya.

Angka Kematian Ibu (AKI) dan Angka Kematian Bayi (AKB) di Indonesia saat ini masih cukup tinggi. AKB Indonesia adalah 32 per 1000 kelahiran hidup (SDKI 2012) dan AKI adalah 228 per 100.000 kelahiran hidup (SDKI 2007). Tingginya angka kematian ibu tersebut disebabkan oleh penyebab langsung dan penyebab tidak langsung. Penyebab langsung kematian ibu adalah adalah perdarahan (40$50 \%$ ), infeksi, ekslampsia, partus lama, dan aborsi yang terkomplikasi. Penyebab tidak langsung salah satunya adalah rendahnya pengetahuan ibu dan keluarga terhadap resiko-resiko kehamilan dan persalinan.

Persiapan yang baik selama kehamilan dan persalinan merupakan salah satu hal yang diperlukan untuk mencegah terjadinya hal-hal yang tidak diinginkan dalam kahamilan dan persalinan. Pengetahuan ibu tentang risiko-risiko yang dapat membahayakan ibu dan janin selama kehamilan perlu diketahui. Apabila ibu hamil termasuk ibu hamil yang berisiko tinggi, maka perlu ditingkatkan kewaspadaan ibu terhadap kehamilannya untuk mencegah hal-hal yang tidak diinginkan. Ibu hamil yang beresiko tinggi adalah ibu hamil yang terlalu muda atau terlalu tua, terlalu banyak anak, memiliki riwayat persalinan yang buruk, pernah mengalami pre-eklampsia, pernah mengalami pendarahan, kelainan letak janin, kelainan medis, dan lain sebagainya.

Pada Jurnal Kesehatan Komunitas kali ini, terdapat empat artikel yang berkaitan dengan kehamilan dan persalinan. Artikel yang ditulis oleh Rika Andriyani diperoleh hasil bahwa faktor yang paling berpengaruh terhadap kejadian pre-eklampsia adalah ibu yang mempunyai riwayat pre-eklampsia. Ibu hamil dengan riwayat pre-eklampsia sebaiknya lebih waspada dengan secara rutin memeriksakan kehamilan ke petugas kesehatan.

Kejadian Intra Uterine Fetal Death (IUFD) di RSUD diteliti oleh Ani Triani yang hasilnya menyatakan bahwa Kadar $\mathrm{Hb}$ dan Paritas merupakan faktor yang paling berpengaruh terhadap kejadian IUFD. Ibu dengan kadar $\mathrm{Hb}<11$ gr\% lebih berisiko terjadi IUFD, demikian pula halnya dengan ibu yang mempunyai paritas yang beresiko yaitu paritas 0 dan $>$ 4 anak.

Komplikasi selama kehamilan merupakan faktor yang paling berpengaruh terhadap persalinan premature. Pernyataan ini berdasarkan penelitian yang diteliti oleh Liva Maita yang menyatakan bahwa ibu hamil dengan komplikasi kehamilan lebih beresiko 6 kali melahirkan persalinan prematur dibandingkan ibu yang tidak mengalami komplikasi kehamilan.

Hasil penelitian Nurlisis didapatkan bahwa faktor yang paling berpengaruh terhadap persalinan abnormal adalah kadar $\mathrm{Hb}$ ibu saat hamil. Ibu dengan $\mathrm{Hb}<11$ gr\% lebih beresiko akan Partus Abnormal 10 kali lebih tinggi dibandingkan ibu yang $\mathrm{Hb}>11 \mathrm{gr} \%$.

Penelitian-penelitian tersebut menunjukkan bahwa ibu hamil yang beresiko tinggi seperti mempunyai riwayat pre-ekslampsia, anemia, mempunyai paritas 0 dan lebih dari 4 , mempunyai resiko yang lebih tinggi untuk terjadinya hal-hal yang tidak diinginkan selama kehamilan dan persalinan. Untuk mengantisipasi jangan sampai hal tersebut terjadi maka pemerikasaan Antenatal Care (ANC) secara teratur dan intensif setiap bulannya dapat mencegah hal-hal yang dapat membahayakan ibu maupun bayinya. Selain itu ibu hamil perlu mengkonsumsi Tablet $\mathrm{Fe}$ secara teratur dan rutin, mengkonsumsi makanan yang bergizi terutama yang tinggi kandungan zat besi seperti sayur sayuran hijau, hati, daging, susu dan lain sebagainya. Untuk ibu yang paritasnya 0 atau disebut dengan nullipara (primigravida) agar dapat berhati-hati menjaga kehamilannya yaitu melalui pemeriksaan ANC secara lengkap dan teratur, pada ibu yang memiliki paritas $>$ 4 sebaiknya mengikuti program Keluarga Berencana (KB).

Kewaspadaan diperlukan untuk ibu hamil terutama ibu hamil yang beresiko tinggi. Kehamilan adalah masa yang membahagiakan, jangan sampai kebahagiaan tersebut menjadi bencana karena kurangnya antisipasi dalam menghadapi kehamilan dan persalinan. 